This is the author's Post-print version (final draft post-refereeing as accepted for publication by the journal). The definitive, peer-reviewed and edited version of this article is published as: van Ham M., van Kempen R. and van Weesep J. (2006) The changing role of the Dutch social rented sector. Journal of Housing and the Built Environment 21(3), 315-335. http://dx.doi.org/10.1007/s10901-006$\underline{\text { 9052-7 }}$

\title{
The changing role of the Dutch social rented sector
}

Maarten van Ham ${ }^{*}$, Ronald van Kempen ${ }^{* *}$ and Jan van Weesep ${ }^{* *}$

*University of St Andrews, School of Geography \& Geosciences, Irvine Building, North Street, St Andrews, Fife, KY16 9AL, UK. Phone +44 (0)1334 463912, Fax +44

(0)1334 463949, E-mail: maarten.vanham@st-andrews.ac.uk

** Utrecht University, Faculty of Geosciences, Urban and Regional research centre Utrecht (URU), P.O. Box 80.115, 3508 TC, The Netherlands, Phone +31 (0)30 253 1399, Fax +31 (0)30 $253 \quad$ 2037, E-mail: r.vankempen@geo.uu.nl, j.vanweesep@geo.uu.nl

\begin{abstract}
The article traces the evolution of the research interests of Frans Dieleman, an academic who combined the development of analytical models with explorations of the policy implications of the changing structure of housing markets. During his long career as a professor of geography, he championed international cooperation in research and played a major role in disseminating the results of Dutch academic studies to an international audience. His own work was concentrated on the analysis of residential mobility. But much of that work also revealed his interest in applying scholarly insights to policy issues. Throughout his career he showed a deep commitment to improving the functioning of the social rented sector in the Dutch housing market. After reviewing some of Frans Dieleman's major contributions to the understanding of the housing market, the article follows in his footsteps by analyzing the current use of social rented housing. In this way, this article provides an update on his field of interest based on recent survey data that underlines the validity of his insights.
\end{abstract}

Key words: housing tenure, social rented housing, income, ethnicity, the Netherlands

\section{Introduction}

Shortly after Frans Dieleman joined the Department of Geography at the Free University in Amsterdam, his first publications saw the light. They reflected interests developed during his graduate studies in the Netherlands and the United States where he had become acquainted with quantitative models - as well as the responsibilities of his new job. Applied geography, research methods and quantitative modeling formed the core of these publications, though eventually he focused on the analysis of the structure and development of housing markets. His first article in a 
(Dutch-language) journal dealt with Christaller's Central Place Theory (Dieleman, 1971a), soon followed by one explaining the principles and applications in geography of the then new tool of factor analysis (Dieleman, 1971b). His first article in English appeared in 1974. Co-authored by his colleague Rein Jobse, it analyzed the spatialeconomic structure of the city of Amsterdam. This study allowed for the use of methods such as cluster and factor analysis and generated an analytical description of the attractiveness of parts of the city for businesses (Dieleman \& Jobse, 1974). After subsequent publications in Dutch, Dieleman's second article in English, co-authored by his former PhD student Sako Musterd (Musterd \& Dieleman, 1981), was once again a methodological paper, this one explaining the use of scaling methods.

After he was appointed to a Chair in Geography in Utrecht, Dieleman made his international breakthrough during the first half of the 1980s, when he started to publish widely on housing and residential mobility in renowned academic journals. Several of these papers were co-authored by two colleagues/friends: Bill Clark in Los Angeles, and Rinus Deurloo in Amsterdam (e.g., Clark et al., 1984; Clark et al., 1986; Deurloo et al., 1987; Clark et al., 1988). Eventually many of his insights in the behavior of households in Dutch and American housing markets were worked into the handbook Households and Housing. Choice and Outcomes in the Housing Market, which became a standard work in residential geography (Clark \& Dieleman, 1996). These publications earned Dieleman and his collaborators a solid reputation among academic researchers of residential mobility, and their work has been widely cited.

Over his career Frans Dieleman cultivated a special interest in the role and functioning of the Dutch social rented sector. In 1986, for example, he published two articles expounding his views on the future of social rented housing: one with Jan van Weesep (Dieleman \& Van Weesep, 1986), the other alone (Dieleman, 1986). Both articles were published in the Tijdschrift voor Economische en Sociale Geografie (Journal of Social and Economic Geography), the flagship journal of the Dutch Geographical Society, to which he became a frequent contributor. In 1988, he and Hugo Priemus prepared a special issue of Built Environment on social housing (Dieleman \& Priemus, 1988). In 1994, he revisited the topic in an article in Urban Studies, where he considered whether or not social rented housing was a "valuable asset or an unsustainable burden" (Dieleman, 1994). That article summarized his contributions to a debate that had been raging for several years. It concerned major changes in Dutch housing policy, which was veering away from its traditional emphasis on affordable rented dwellings and toward market-rate housing for homeowners. A few years later, he and Hugo Priemus published another paper on social housing policy in Urban Studies, underlining his longstanding fascination with the fact that many issues kept reappearing in Dutch housing as its problems proved to be resistant to the flurry of policy changes (Priemus and Dieleman, 2002).

With his research on social rented housing, Frans Dieleman inspired colleagues in the Netherlands and abroad to deal with the questions he raised concerning the changing role of social rented housing (see Murie and Priemus, 1994; Meusen and Van Kempen, 1994; 1995; Van Kempen et al., 2000; Van Kempen and Priemus, 2002; and Schutjens et al., 2002). Together with his own writings, this rich collection of quantitative and qualitative analyses has not only produced a detailed picture of the (now) rapidly changing tenant population of the social rented sector in the Netherlands but has also generated a deep understanding of its causes and its effects.

Paying homage to Frans Dieleman, who considered the social rented sector so important for an understanding of Dutch housing dynamics, this paper analyzes how this sector has changed in recent years. It looks mainly at the user side, asking who 
lives in the social rented sector nowadays and how this tenant population has changed. This analysis is intended as an update on the articles mentioned above. To that end, it uses recent data and evaluates some of the ideas put forward by Frans Dieleman in his long-term work on social rented housing; are his insights and forecasts still valid? The analyses are based on the Netherlands' Housing Demand Surveys (WBOs) of 1998 and 2002, which are representative for the Netherlands' population. Such periodic data sets were a major source for much of the research that Frans Dieleman undertook in his quest to check his academic insights against empirical evidence.

\section{Frans Dieleman on the Dutch social rented sector}

In 1986, a few years before one of the most dramatic overhauls of social housing policy in the past fifty years took place in the Netherlands, Frans Dieleman published "The future of Dutch housing: a review and interpretation of the recent literature". There, he described some of the then contemporary housing market trends and offered his assessment of the developments that he expected to occur (Dieleman, 1986, p. 336) and that have indeed come to pass. The main ones are summarized below.

With respect to demographic change, Dieleman expected the number of households to increase substantially. In 1982, there were about 5.1 million households in the Netherlands, 60 percent more than in 1960. Applying the then widely used PRIMOS model (Heida and Gordijn, 1985), he forecast that by the year 2000 the number of households would have grown by some 960,000 to about 6 million. The population would be older, mainly because of a persistently low birth rate and a declining death rate. His prognosis was that the number of young households (18-26 years) would decrease drastically. Meanwhile, the number of persons between 39 and 54 years of age would rise substantially, as would the number of elderly households, although to a lesser extent. Interestingly, Dieleman hardly mentioned the changing ethnic dimension of the population dynamics. He was obviously aware of the magnitude of the immigration of Surinamese and Mediterranean people between 1960 and 1982. Yet he did not perceive the increasing numbers of households of foreign birth or with an ethnic background as significant for the future of Dutch (social rented) housing. As the new immigrants generally belonged to the low-income groups, their presence in the social rented sector could have been expected to increase in the 1980s and 1990s.

In general, it is easier to predict demographic changes than economic developments. Dieleman did note a decline in purchasing power for most income categories between 1979 and 1986. That was a period of economic recession followed by an agonizingly slow recovery, accompanied by stagnation in the owner-occupier housing market and unexpectedly strong demand for affordable rental units. As he saw no grounds to believe that personal incomes would then grow rapidly, he anticipated a sustained demand for low-cost rental housing (Dieleman, 1986, pp. 339$340)$.

With respect to housing market developments in the intermediate term, Dieleman made some interesting observations (p. 340):

- The combination of slowly increasing incomes and decreasing interest rates for mortgage loans would make the purchase of a house a good proposition for anyone who could indeed afford to buy.

- $\quad$ This would be underlined by the continuing increase of rents in the social rented sector, in spite of - or because of -governmental rent regulation. 
- Because the steady growth of the budget for housing subsidies under the entitlement programs would become unsustainable, the housing budget would become a likely target for substantial cuts in the near future (see also Dieleman and Van Weesep, 1986).

As a geographer, Dieleman was greatly interested in the spatial variations of housing market developments. He predicted that suburbanization would continue after 1986, although since overall development would slow, the trend would be sustained at a lower level than in the 1970s and early 1980s. At the same time, people between 24 and 44 years of age would, in his view, increasingly dominate the housing market in the cities. The urban areas would remain the action space of large numbers of lowincome households, who would exert a permanent demand for affordable housing. New developments in the urban labor market (more high-tech and computer-related activities) would increase the number of high-wage jobs, thereby increasing the number of households looking for more expensive homes in Dutch cities (Dieleman, 1986, p. 342). Putting such trends together, Dieleman recommended giving lowincome households high priority for access to affordable rental housing (p. 342). In that vein, Dieleman ended his article by concluding that "This issue will reappear on the political agenda in the coming years until a satisfactory solution is reformulated." (p. 342) At the time of writing, even he could not have known how true his prediction would turn out to be.

In 1994, Frans Dieleman discussed the changing role of the Dutch social rented sector from an international perspective. In his review of the contemporary literature on the relation between housing markets and government intervention, he demonstrated just how special the Dutch situation was. By the 1980s, extensive cutbacks in the housing sector had already become common practice in many European countries. In the Netherlands, though, the retreat of the national government was far less dramatic (see Boelhouwer and Priemus, 1990). In line with the depiction of Dutch society by Van Kersbergen and Becker (1988), the Dutch tradition of extensive regulation of housing and its persistence in the 1980s were interpreted in terms of social solidarity: the factors 'capital and labor' were seen as 'social partners'. By extension, there was a moral obligation on the part of the 'strong' to assist the 'weak'. This matched the government's desire to keep inflation low and prevent rapid growth of income inequality. Given the continuing albeit slowly diminishing outlays of the government for housing support, the sector was still widely considered to be an instrument of anti-cyclical policies in times of economic downturn. In fact, the persistently high demand for housing because of a high birth rate and changing attitudes towards divorce and co-habitation kept housing high on the political agenda for decades (Dieleman, 1994).

Because of the longstanding and deep-seated public support for social housing, the Dutch social rented stock was relatively new and well equipped in the early 1990s. The quality of the stock reflected the official standards for new housing and the concerted efforts by national and local governments to renovate or replace derelict housing through an elaborate urban renewal process (Dieleman, 1994). The high level of rent support meant that even though housing costs increased, they remained largely affordable. Consequently, the Dutch social rented housing stock was neither marginal nor residual (Meusen and Van Kempen, 1995). And because of the large size of the sector, those urban neighborhoods that were dominated by social rented housing were not necessarily swamped by large numbers of low-income households. This kept the incidence of spatial segregation by income quite low (Dieleman, 1994). 
There was, however, a downside to all this. Because of the long and steadily expanding construction boom in social rented housing after World War II, the proportion of the Dutch dwelling stock destined for homeownership was relatively low, especially in the (largest) cities. Households in the medium and higher income brackets who wanted to become homeowners generally had to look outside the cities. As a result of the ensuing selective out-migration, cities came to house a growing share of low-income households. By the end of the 1980s, this was widely perceived as a problem (see below). But according to Dieleman (1994), the real problem with the large social rented sector was not its uneven distribution across income groups but the financial burden of housing low-income households. In his assessment, the huge and ever-growing amounts of money required to maintain housing subsidies on the demand side (e.g., the individual rent subsidies) as well as on the supply side would gradually put unsustainable pressure on the national budget. He therefore expressed the view that the focus of national housing policies would have to shift. Policy would have to allow greater reliance on the private sector; that is, it should shift its emphasis toward promoting (affordable) homeownership. In the 1990s, more changes were to come about; both the character and the occupants of social housing were about to change dramatically.

\section{Important changes in the Dutch housing market}

Since the publication of his article on the future of Dutch housing in 1986, Dutch society has changed in many respects, with major consequences for the role of the social rented sector. Many of these changes were predicted, explicitly or implicitly, in his work. To follow one of Dieleman's golden rules - always check assumptions against empirical developments - we will now briefly consider how the changes mentioned above actually manifested themselves.

\section{Increasing number of households}

Indeed, the number of households has grown immensely since the beginning of the 1980s. Dieleman had predicted an increase of 960,000 households between 1982 and 2000. The actual change amounted to an astonishing growth - by 1.7 million households - leading to a total of 6.8 million households in the Netherlands in 2000. Between 2000 and 2004, this number rose further to over than 7 million (Figure 1). The effect on the housing market of this overall increase was aggravated by the changing household composition: the growth in the number of singles and two-person households and the relative decline in the number of families. 
Figure 1: $\quad$ Number of households in the Netherlands, 1978-2004.

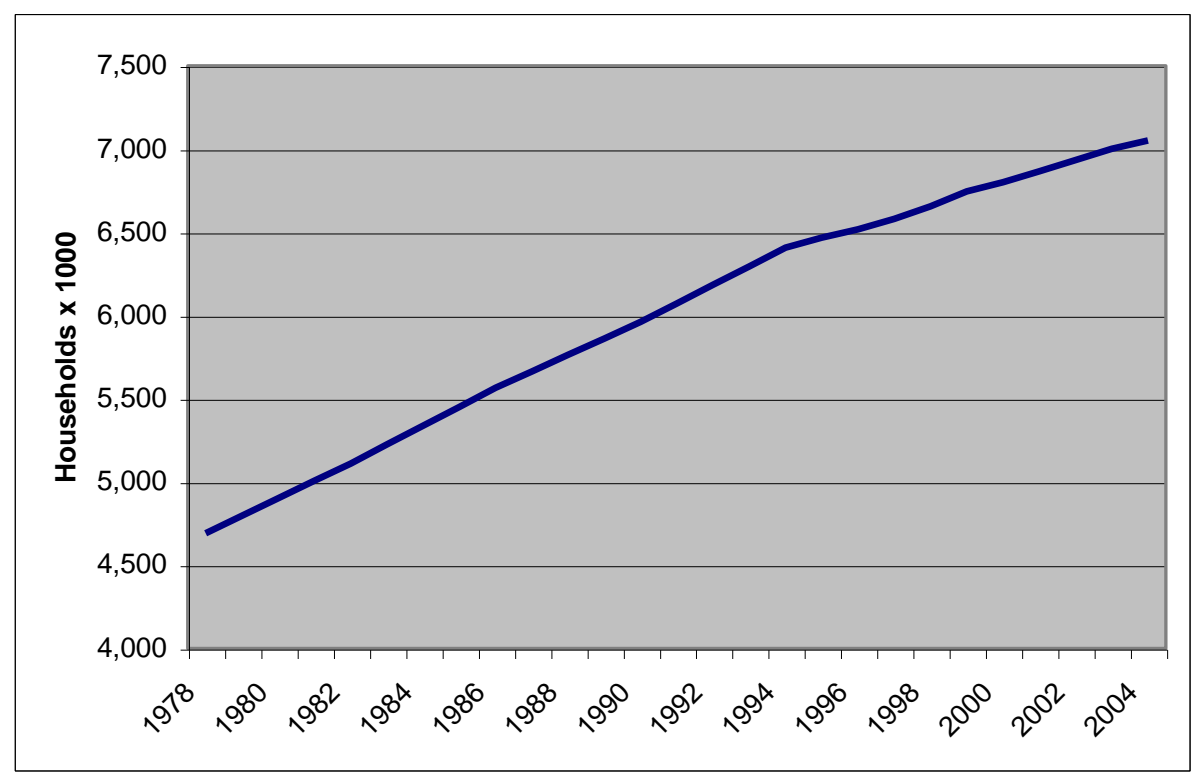

Source: Ministerie VROM, 2004; CBS Statline, 2005; CBS, 2005

The changing ethnic composition of the Dutch population, especially that of its largest cities, was unprecedented. As noted above, this specific development was hardly mentioned by Frans Dieleman. In the Netherlands as a whole, 10.3 percent of the population now falls into the category of people of non-Western origin or descent, while in 1972 this was less than two percent (Figure 2). The shares in the large cities are significantly higher. In Rotterdam, 34.6 percent of the total population is now identified as having a non-Western background. In Amsterdam the percentage is 33.9, in The Hague 31.2, and in Utrecht 20.4.

Figure 2: $\quad$ Percentage of people of non-Western origin in the Netherlands, 1972-2005

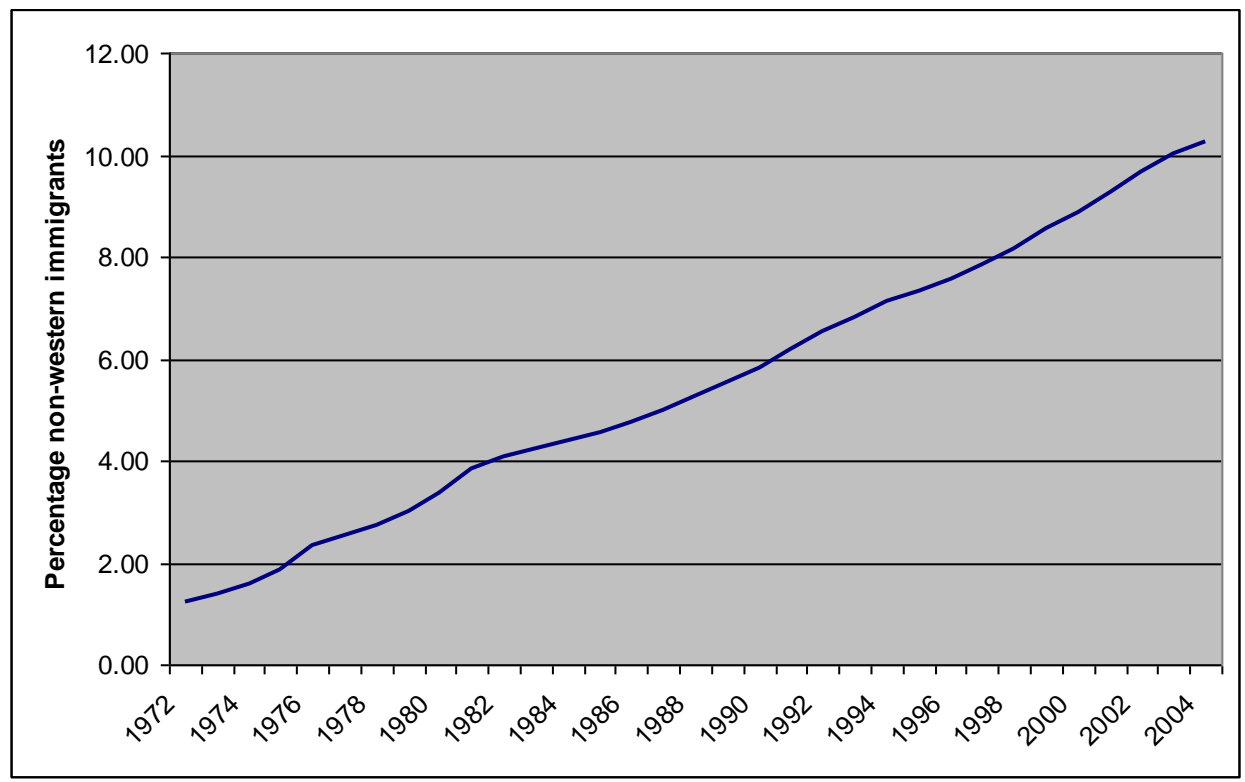

Source: CBS Statline, 2005

\footnotetext{
${ }^{1}$ A person's origin or descent is determined on the basis of country of birth of the person in question (1st generation) or that of the mother (2nd generation), unless the mother was born in the Netherlands. In that case the country of birth of the father is selected as the indicator.
} 


\section{Income developments}

Nominal personal incomes grew steadily between 1973 and 1998 (Figure 3). Correcting for inflation, this corresponds to Dieleman's expectation that real incomes would increase slightly during the 1980s. As Figure 3 shows, real personal incomes fluctuated over time. There was a strong decline in the early 1980s, an increase in the second half of the 1980s and again a slight decrease in the $1990 \mathrm{~s}^{2}$. It should be kept in mind that the incomes shown are average personal (not household) incomes. The figures therefore mask the fact that household incomes have become polarized, with an increasing number of low-income households. At the household level, incomes have risen dramatically since the early 1970s because of the rise in dual-earner households.

Figure 3: Nominal incomes and real incomes (1996 disposable incomes), 1973-1999.

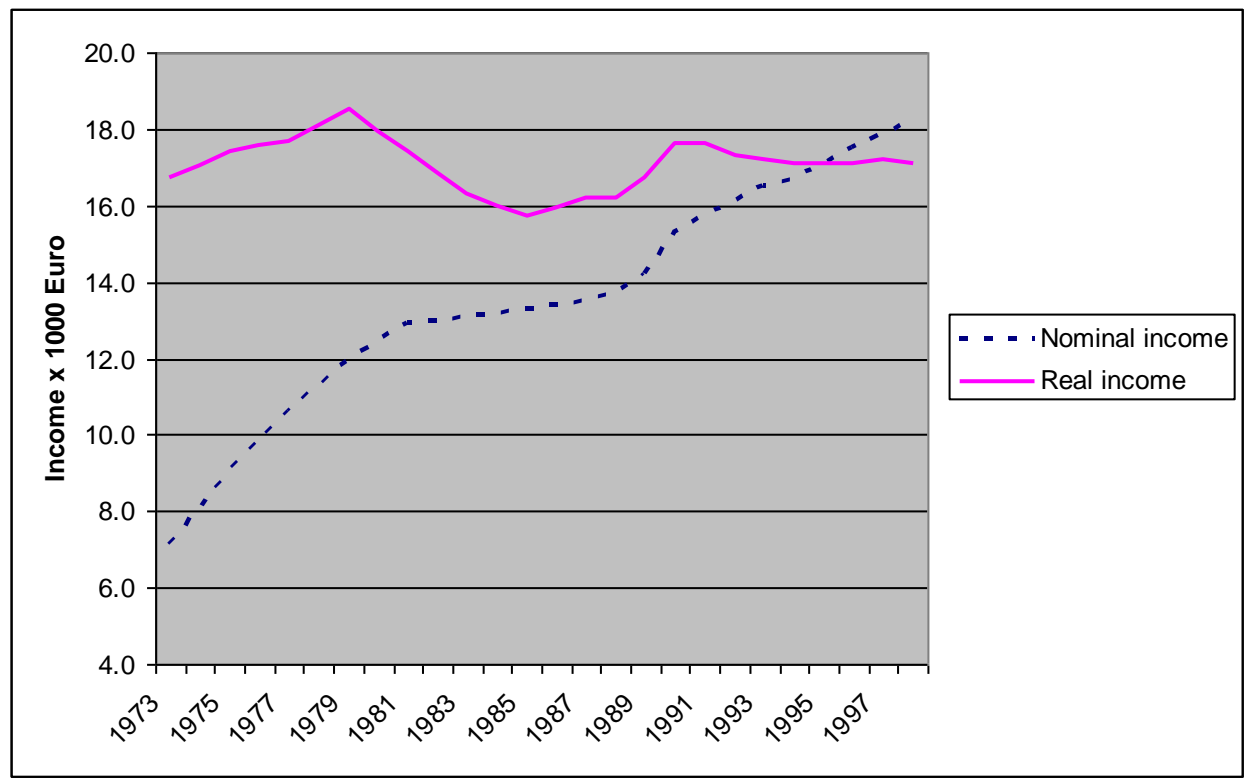

Source: CBS Statline, 2005

\section{Renting or buying?}

The tenure composition of the housing stock in the Netherlands has changed drastically since World War II (Table 1). Up through the end of the 1980s, large numbers of social rented dwellings were built at a fluctuating pace. This new construction program caused the share of the social rented sector to rise to 41 percent in 1990. In the 1990s, the proportion of social rented dwellings started to decline, mainly due to the increased number of owner-occupied dwellings. One of the aggregate effects of this relative change is that by 2002, only 35 percent of the Dutch housing stock was in the social rented sector. In the four largest cities, these percentages remained higher: 57 percent in Rotterdam, 55 percent in Amsterdam, 41 percent in Utrecht and 36 percent in The Hague (Ministerie VROM, 2004). Whereas private rent was the most prevalent sector in the 1947 Housing Census, the private rented sector has declined enormously since the Second World War, at least in relative terms. In part, this is because more and more dwellings were built in the social rented and owner-occupied sector. But it is also partly the effect of a tenure

\footnotetext{
${ }^{2}$ Disposable income per person is defined as gross income minus social insurance premiums (both the worker's and the employer's contributions) and taxes; where applicable, other structural deductions such as alimony payments are also taken into account.
} 
conversion of properties from private to social rent and to owner-occupation. By 1970 the owner-occupied sector was the biggest of the three sectors.

Currently, the majority of all households in the Netherlands live in owneroccupied dwellings, although in the big cities the social rented sector is still the predominant tenure. As Dieleman had stated, buying a house is a good choice for those who can afford to do so. But especially in the large cities, it has been hard to find suitable dwellings to buy, either because they were relatively scarce or because they were unaffordable to many low-income urban residents. Clearly, many households remain dependent on low-cost housing, i.e. social rented housing.

Table 1: $\quad$ Tenure in the Netherlands, 1947-2002 (percent of total housing stock)

\begin{tabular}{llll}
\hline Year & Social rent & Private rent & Owner-occupation \\
\hline 1947 & 12 & 60 & 28 \\
1960 & 23 & 47 & 30 \\
1965 & 26 & 41 & 33 \\
1970 & 31 & 34 & 35 \\
1975 & 34 & 27 & 39 \\
1980 & 36 & 22 & 42 \\
1985 & 39 & 18 & 43 \\
1990 & 41 & 14 & 45 \\
1995 & 38 & 14 & 48 \\
2000 & 36 & 11 & 53 \\
2002 & 35 & 11 & 54 \\
\hline
\end{tabular}

Source: Van Kempen \& Priemus, 2002; updated with Ministerie VROM, 2004

Increasing housing costs

In 1986, Dieleman predicted that the cost of social rented dwellings would increase substantially; that proved to be perfectly true (Figure 4). Yet escalating rents have not moved the social rented sector outside the reach of low-income households. Maintaining the individual rent subsidies at a generous level has helped many households bridge the gap between rent and income. Not only have the rents increased, but the prices of owner-occupied dwellings have also increased very rapidly, especially since 1996 when mortgage interest rates were very low. Since the early 1980s the nominal prices of new owner-occupied dwellings have almost tripled (Figure 5). This has trapped low-income households - and even large numbers of households with a middle income - in the rented sector; they are still unable to buy a suitable home. 
Figure 4: $\quad$ Average gross rent per month (Euros) $)^{3}$

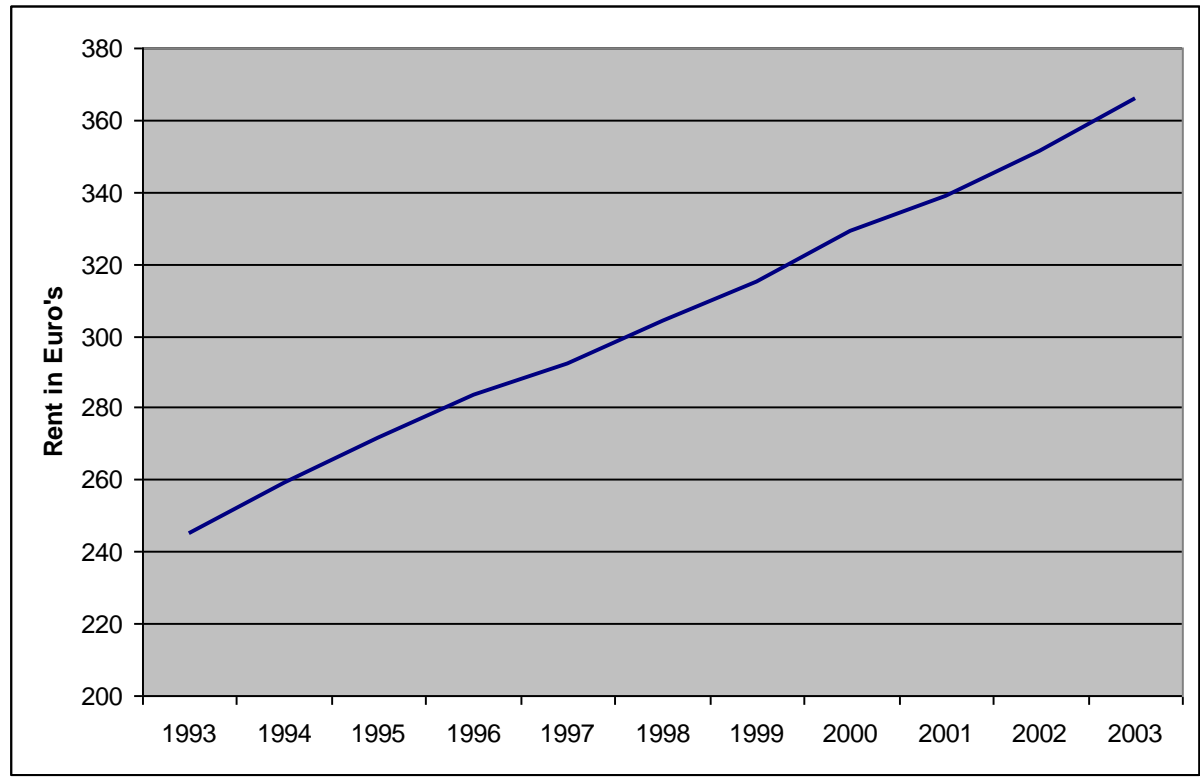

Source: Ministerie VROM, 2000; 2004

Figure 5: $\quad$ Nominal prices of new owner-occupied dwellings (Euros)

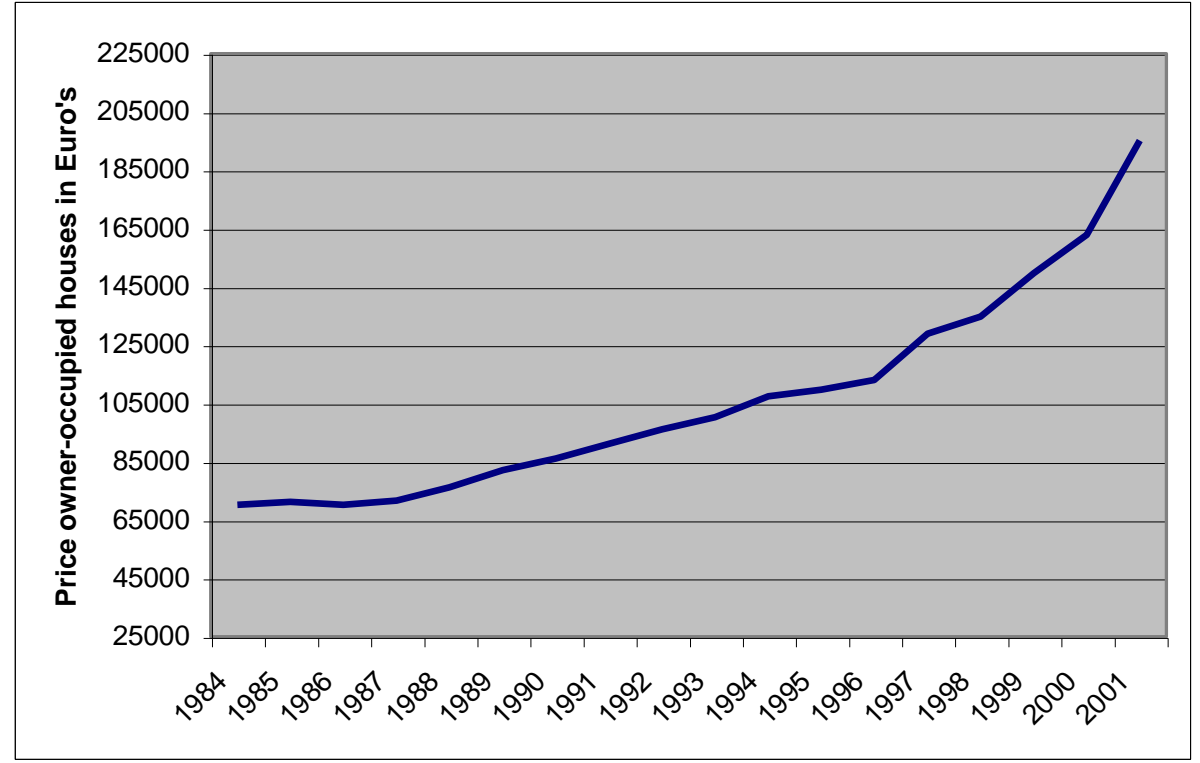

Source: Ministerie VROM, 2004

The changing welfare state and the effects on social housing

Since the end of the 1980s, changes have been made in housing policy, mainly to regain control over run-away housing budgets. The overall effect has been a dramatic retreat of government from housing. The main changes have been dealt with extensively in several other publications (e.g., Van Kempen et al., 2000; Van Kempen and Priemus, 2002). For this study we limit the overview to a summary of the major changes that have affected the position of the social rented sector in the Dutch housing market.

Because many middle- and higher-income households were more or less forced to move out of the cities if they wanted to become homeowners, the national government started to boost the supply of homeowner dwellings by the end of the 1980s

\footnotetext{
${ }^{3}$ These are prices for all rental units, including the private rented sector.
} 
(Dieleman, 1994). Yet there was another reason for this change of policy: because many households with relatively high incomes lived in rather inexpensive social rented dwellings for lack of alternatives, they hindered low-income households and starters on the housing market in their attempts to find suitable new dwellings. This was widely perceived as a misappropriation of (former) subsidies, a situation that needed to be rectified through new measures. There is extensive documentation on this sea-change in Dutch housing policy.

But the budget cutbacks and the abolition of the generic operating subsidies for the social rented sector put newly built dwellings beyond the reach of tenants with modal incomes, let alone lower incomes (Priemus, 1995). The fundamental changes were announced in the government's white paper "Housing in the 1990s" (Ministerie VROM, 1989). In broad strokes, the changes may be described as follows:

- The national government reduced its role in social housing by transferring responsibility to local governments and to the social housing associations.

- Construction subsidies for new social rented dwellings and operating subsidies were abolished. From then on, the housing associations had to pay for maintenance from their operating budgets and reserves. Rather than having access to soft loans from public funds, they have had to borrow on the capital market for new construction.

- While the system of individual rent subsidies was retained, major changes were made to ensure its future viability (Van Kempen et al., 2000).

In the 1990s, in the wake of these changes, the Ministry of Housing showed that it understood how the new market-oriented housing policies could lead to undesired spatial concentrations of low-income households in the cities. In line with its priorities in the urban policy field, the government sought to prevent that from happening. But it could not let up on its attempts to move households with middle and higher incomes out of the social rented sector. The only realistic option was to restructure the housing stock of the areas in question (see also Schutjens et al., 2002). Building more expensive dwellings in the older neighborhoods to attract - or retain - higher-income households seemed to be the most effective solution. This strategy would have to be combined with the demolition of inexpensive rented dwellings, i.e. parts of the social rented stock, to reach the desired effects. The intention was to upgrade parts of the social rented stock, again with the idea of attracting more middle- and higher-income households. This policy of urban restructuring was put forward in a white paper (Ministerie VROM, 1997).

The proposed policy became a hotly disputed issue, with several housing researchers taking strong positions against it. They predicted that the shrinkage of the social rented stock would in the end lead to higher concentrations of low-income households, because affordable dwellings would increasingly be found in only a small number of places. Another major point of criticism focused on the motives to dilute the concentrations; there was no clear scientific evidence that spatial concentrations of poor households would be disadvantageous to these low-income groups themselves (see, e.g., Van Kempen and Priemus, 2002).

All the separate initiatives and decisions were combined in a comprehensive policy report issued in late 2000 that was meant to provide the rationale for an entirely different form of public intervention in housing. The key concept of this 'policy for the twenty-first century' was defined as freedom of choice for the housing consumer within reasonable market and social constraints (Ministerie VROM, 2000). The government committed itself to promote the population's sense of ownership of the housing stock and the residential environment. It was expected that both commitment 
and satisfaction could be maximized by transferring the authority over maintenance decisions to current homeowners in existing neighborhoods and shifting the authority over design elements to prospective residents in growth areas; in both cases, this would be achieved by removing unreasonable permit requirements. The government would still uphold its commitment to support people in vulnerable positions in order to prevent the emergence of a pattern of social exclusion. However, the welfare and care provisions would be fine-tuned to meet demonstrated needs. The increasingly one-sided composition of the urban population compared to the national profile was to be rectified by a major attempt to upgrade the urban residential environment. This would be done without ignoring what is considered a legitimate desire of some to live in a low-density environment outside the cities in the countryside. Only by removing strict spatial development limitations would the full potential of freedom of choice be realized. Obviously, commitment on the part of government agencies to promote deregulation is not sufficient to attain such lofty goals; success will also depend on adequate budgetary instruments.

\section{Current occupants of social rented housing in the Netherlands: hypotheses}

The above-mentioned changes in Dutch society and the recent market-oriented housing policies have presumably had an impact on the role of the social rented sector in the housing market. In this section, we use the 1998 and 2002 Housing Demand Surveys to analyze how the social rented sector has changed over the last few years. We look at who lives in the social rented sector nowadays and how the tenant population changed in recent years. Because we want to formulate hypotheses, we start with a brief review of the main conclusions drawn in earlier studies:

- $\quad$ During the 1980s and 1990s, the social rented sector was characterized by an increasing presence of households from the lower income deciles, while the number of those in higher deciles diminished (Van Kempen \& Priemus, 2002, p. 243).

- This situation was aggravated during the 1990s, when the number of tenants in the two lowest income deciles increased, indicating that the Dutch social rented sector was becoming a refuge for the very poor while even households with marginally higher incomes were moving out (Van Kempen \& Priemus, 2002, p. 243).

- The higher-income groups have rapidly been abandoning the social rented sector for homeowner dwellings. This process started in earnest during the 1980s but became much more marked in the 1990s (Van Kempen \& Priemus, 2002, p. 243). Clearly this development was related to the increased production of owner-occupied dwellings during the past two decades.

- In the four largest cities, the share of households in the higher income deciles living in the social rented sector was much larger than in the country as a whole. According to Van Kempen and Priemus (2002, p. 244) this was the result of the lack of opportunities in cities (small share of owner-occupied homes in the cities, especially in Amsterdam and Rotterdam). But presumably it also has to do with the fact that higher-income people are comfortable in relatively inexpensive but decent social rented dwellings. That tenure allows them to minimize their housing expenses and maximize their disposable income.

- Income seems to be the most important determinant of the tenure allocation for the country as a whole, as well as for the four largest cities (Van Kempen et al., 2000, p. 516). This outcome confirms the results of many other studies, 
including those conducted by Frans Dieleman and his colleagues (see, e.g., Clark and Dieleman, 1996). Between 1981 and 1993, the effect of income increased: higher-income households had more chance of ending up in an owner-occupied dwelling. Again this was an effect of the expansion of the homeowner sector over the last two decades. More and more higher-income households took advantage of opportunities to move from a rented unit into a homeowner dwelling.

- Households of ethnic descent are relatively more prevalent in social rented housing than indigenous Dutch households. Differences in income, age and household size do not fully explain this overrepresentation (Van Kempen et al., 2000, p. 518). An additional explanation might be that people from ethnic minority groups have less secure jobs and therefore have more difficulty becoming homeowners. Banks might also discriminate in offering mortgages although this is hard to prove (Aalbers, 2003). Another explanation might be that the first generation of immigrants started their housing career relatively late because it took several years for their family to join them. The delay might have prevented this group from entering the owner-occupied market.

In light of findings from previous studies and developments in the Netherlands, we can now formulate several hypotheses. Many studies have shown income to be the prime determinant of tenure segmentation, even in an advanced welfare state such as the Netherlands. We assume that income is still the prime determinant of tenure segmentation. Thus, we hypothesize that between 1998 and 2002, the social rented sector increasingly housed the lowest-income groups. Two developments are thought to be responsible for this. First, the dramatic price inflation in the owner-occupied sector will increasingly form a barrier to people from lower-income groups, preventing them from entering this segment of the housing stock; they will have become trapped in the (social) rented sector. Second, growth of the owner-occupied sector causes a selective outflow of middle- and higher-income groups from social renting. Those who can afford to move out of the social rented sector do so; the rest stay there for lack of choice. We therefore hypothesize that households in the top income deciles will have been gaining access to the owner-occupied sector. Finally, based on earlier studies, we expect the social rented sector to remain important for households of ethnic descent.

\section{Data and methodology}

To test the main hypothesis, individual-level data were taken from the Netherlands Housing Demand Survey (WBO) that was conducted in 1998 by Statistics Netherlands and from the 2002 Housing Demand Survey (WBO) that was administered by the Ministry of Housing, Spatial Planning and the Environment (VROM). The data from both surveys are available through the Netherlands Scientific Statistical Agency. The WBO 1998 contains data on just over 120,000 respondents, the WBO 2002 on just over 75,000 respondents. The research population captured in the WBOs is representative of the Netherlands' population aged 18 and over and not living in an institution. The dataset includes detailed information on individual and household characteristics.

All independent households in the survey were selected for inclusion in the analysis. We excluded any individuals living with their parents, living in shared housing such as student accommodation, and people living in non-housing 
accommodation such as boats or caravans. Furthermore, we excluded any respondents who do not fit in one of our ethnicity categories: indigenous Dutch, Surinamese, Antillean, Indonesian, Turkish and Moroccan. These categories were based on the country of birth of the respondent or the respondent's parents. Because we were interested in persons living in social rented housing, we also excluded all respondents living in private rented housing from the multivariate analyses. The result was a total of 141,959 respondents, 84,197 of whom lived in owner-occupied dwellings and 57,762 in social rented dwellings.

For the descriptive analyses, the respondents were weighted with the household weight available in the WBOs. After weighting, the WBOs' distribution of households living in social rented housing, private rented housing and the owneroccupied sector corresponded to the actual variation in the Netherlands in 1998 and 2002. Weighting was also necessary for the multivariate analyses because persons living in social rented housing were overrepresented in the WBO 2002. This resulted in a higher percentage of households in social rented housing compared to the real situation. The weights used in the multivariate analyses were adjusted so that the total number of respondents - and therefore the standard errors - remain unchanged. As a check, the models were also run using the unweighted data (not shown here). The results - i.e., parameters and significance levels - derived from these models do not differ from those derived from the models shown in this paper. The only difference is the parameter for the year 2002, which is positive in the model without interaction effects. This reflects an overrepresentation of persons in social housing in the 2002 survey, while in reality the number of households in social housing had decreased.

Table 2: $\quad$ Variable summary statistics $(N=141,959)$

\begin{tabular}{|c|c|c|}
\hline Variable name & Categories & $\mathrm{N}(\%)$ \\
\hline \multicolumn{3}{|c|}{ Tenure (dependent) } \\
\hline & Owner-occupied & $84,197(59.3)$ \\
\hline & Social-rent & $57,762(40.7)$ \\
\hline \multicolumn{3}{|l|}{ Income segment } \\
\hline & highest $25 \%$ & $37,714(26,6)$ \\
\hline & $3 \mathrm{rd} 25 \%$ & $36,424(25.7)$ \\
\hline & 2nd $25 \%$ & $34,155(24.1)$ \\
\hline & Lowest $25 \%$ & $34,155(24.1)$ \\
\hline \multicolumn{3}{|c|}{ Household composition } \\
\hline & Family household & $94,545(33.4)$ \\
\hline & Single person & $41,605(29.3)$ \\
\hline & Two-person household & $45,546(32.1)$ \\
\hline & One-parent household & $7,335 \quad(5.2)$ \\
\hline \multicolumn{3}{|c|}{$\begin{array}{l}\text { Age of head of the } \\
\text { household }\end{array}$} \\
\hline & under 25 & $3,833 \quad(2.7)$ \\
\hline & $25-44$ & $57,642(40.6)$ \\
\hline & $45-54$ & $29,206(20.6)$ \\
\hline & $55-64$ & $21,439(15.1)$ \\
\hline & $65-74$ & $16,938(11.9)$ \\
\hline & over 75 & $12,984 \quad(9.1)$ \\
\hline \multicolumn{3}{|c|}{$\begin{array}{l}\text { Ethnicity / foreign origin of } \\
\text { head of household }\end{array}$} \\
\hline & Indigenous Dutch & $129,982(91.6)$ \\
\hline & Surinamese/Antilleans/Aruban & $3,701 \quad(2.6)$ \\
\hline & Indonesians & $4,599 \quad(3.2)$ \\
\hline & Turks and Moroccans & $3,677 \quad(2.6)$ \\
\hline
\end{tabular}


Location of residence

Rest of Netherlands $\quad 124,662(87.8)$

4 largest cities

$17,297(12.2)$

Year

1998

$87,862(61.9)$

2002

$54,097(38.1)$

Source: WBO 1998 and WBO 2002, own calculations

The dependent variable for the multivariate models is binary and indicates whether respondents live in owner-occupied housing (0) or social rented housing (1). Given the binary character of the dependent variable, logistic regression models were used. These models are designed to isolate the effect of each one of a set of ordinal independent variables on a dichotomous dependent variable. Here, this model helps us determine whether, for instance, income or age explains why some households are in social rented housing, while others are homeowners. The technique employs 'odds', defined as the chance that a given event will occur relative to the chance of it not occurring. The outcome is a regression model, which estimates the effect of a change by one unit in an independent variable on the logarithm of these odds (the 'log-odds'). The use of the logarithmic transformation facilitates the interpretation of the outcomes by keeping the estimated values between 0 and 1 . At the same time, the effects of the remaining variables are held constant. This means that, for instance, if the parameters of the model show that the housing situation of low-income households is worse than that of middle-income households, this discrepancy is not caused by a difference in the average age of the two income categories or any other variable selected for the analysis (Schutjens et al., 2002).

Several independent variables have been included in the models. Variable summary statistics can be found in Table 2 . In this analysis, we are mainly concerned with the effect of income on tenure. Although income is available as a continuous variable in the WBOs, income quartiles were used in the analysis. This standardization helps us compare the effect of income for the two years in the analysis. The distribution of respondents over the quartiles as shown in Table 2 is not perfect because the private rented sector was excluded after the quartiles were defined. Also the variables 'age of the head of the household' and 'household type' were included in the model. Further, several dummies for 'ethnicity/foreign origin' were included. We only included those groups that were large enough in the WBOs to form separate categories: Indigenous Dutch, Surinamese/Antillians/Arubans, Indonesians, Turks and Moroccans. Finally, a dummy was included in the models to indicate whether or not the respondents live in one of the four largest cities of the Netherlands, and another dummy was included to identify the year of the interview.

\section{New empirical results}

The main focus of this research is on the extent to which income and ethnicity/foreign origin explains whether households live in social rented dwellings and whether changes in the effects of these variables occurred between 1998 and 2002. The relationship between income and ethnicity will be explored in a series of bi-variate analyses, as summarized in Tables $3-6$. Table 3 gives an overview of the tenure segmentation of the social rented, the private rented and the owner-occupied stock in the whole country for the years 1998 and 2002. In 1998, for example, 52.0 percent of the population in the lowest income decile were living in the social rented sector, indicating that the lowest income deciles are concentrated in the social rented sector. 
This association was even stronger in 2002; the lowest income deciles were more concentrated in the social rented sector, while the presence of the highest income deciles decreased in the social rented sector. This indicates - as hypothesized - that while the social rented sector as a whole was shrinking (from 36.6 to 35 percent), it became increasingly more important for the lowest-income groups between 1998 and 2002.

The importance of the private rented sector decreased for all income deciles between 1998 and 2002. Again as hypothesized, the owner-occupied sector became more popular among the higher-income groups. In the highest income decile, the share of owner-occupation increased to almost 90 percent.

Table 3: $\quad$ The changing tenure segmentation in the Netherlands: percentages per income decile in the social rented sector, the private rented sector and owner-occupation, 1998 and 2002

\begin{tabular}{|c|c|c|c|c|c|c|}
\hline & \multicolumn{2}{|c|}{ Social rent } & \multicolumn{2}{|c|}{ Private rent } & \multicolumn{2}{|c|}{ Owner-occupation } \\
\hline & 1998 & 2002 & 1998 & 2002 & 1998 & 2002 \\
\hline Total & 36.7 & 35.0 & 12.4 & 10.8 & 50.8 & 54.2 \\
\hline $1^{\text {st }}$ decile & 52.0 & 58.4 & 20.9 & 17.3 & 27.1 & 24.3 \\
\hline $2^{\text {nd }}$ decile & 62.0 & 65.0 & 15.7 & 13.0 & 22.3 & 22.0 \\
\hline $3^{\text {rd }}$ decile & 57.0 & 59.3 & 14.8 & 12.3 & 28.2 & 28.4 \\
\hline $4^{\text {th }}$ decile & 51.6 & 47.3 & 13.6 & 11.2 & 34.9 & 41.5 \\
\hline $5^{\text {th }}$ decile & 40.5 & 38.9 & 13.5 & 10.7 & 46.0 & 50.4 \\
\hline $6^{\text {th }}$ decile & 32.2 & 30.3 & 10.6 & 9.2 & 57.3 & 60.4 \\
\hline $7^{\text {th }}$ decile & 26.1 & 22.8 & 9.6 & 6.5 & 64.3 & 70.7 \\
\hline $8^{\text {th }}$ decile & 20.1 & 15.2 & 9.2 & 5.9 & 70.6 & 78.9 \\
\hline $9^{\text {th }}$ decile & 14.1 & 10.5 & 7.6 & 5.9 & 78.3 & 83.6 \\
\hline $10^{\text {th }}$ decile & 9.2 & 5.7 & 7.2 & 4.6 & 83.5 & 89.7 \\
\hline
\end{tabular}

Source: WBO 1998 and WBO 2002, own calculations (weighted)

When the same calculations were carried out for the four largest cities in the Netherlands (Table 4), the overall picture was the same. Between 1998 and 2002, the social rented sector became more important for the lowest-income groups and less important for the higher-income groups. In the cities, the owner-occupied sector seems to have become slightly less important for the lower-income groups, but much more important for the highest income groups. Between 1998 and 2002 the share of persons in the highest income decile among the residents in the owner-occupied sector increased from 60.0 to 74.6 percent.

Table 4: $\quad$ The changing tenure segmentation in the four largest cities of the Netherlands: percentages per income decile in the social rented sector, the private rented sector and owner-occupation, 1998 and 2002

\begin{tabular}{lllllll}
\hline & \multicolumn{2}{c}{ Social rent } & \multicolumn{3}{c}{ Private rent } & \multicolumn{2}{c}{ Owner-occupation } \\
\cline { 2 - 7 } & 1998 & 2002 & 1998 & 2002 & 1998 & 2002 \\
\hline Total & 51.5 & 49.6 & 23.2 & 20.9 & 25.3 & 29.5 \\
& & & & & & \\
$1^{\text {st }}$ decile & 55.9 & 62.9 & 33.2 & 27.4 & 10.9 & 9.7 \\
$2^{\text {nd }}$ decile & 65.3 & 72.4 & 24.0 & 18.7 & 10.7 & 8.9 \\
$3^{\text {rd }}$ decile & 63.4 & 67.6 & 25.2 & 20.7 & 11.4 & 11.7 \\
$4^{\text {th }}$ decile & 60.5 & 56.0 & 24.0 & 21.6 & 15.4 & 22.4 \\
$5^{\text {th }}$ decile & 47.1 & 50.7 & 28.2 & 22.3 & 24.7 & 27.0 \\
$6^{\text {th }}$ decile & 46.8 & 46.2 & 25.4 & 19.4 & 27.8 & 34.4 \\
$7^{\text {th }}$ decile & 43.5 & 37.0 & 24.0 & 14.0 & 32.5 & 49.0 \\
$8^{\text {th }}$ decile & 39.7 & 29.8 & 20.6 & 18.4 & 39.7 & 51.8 \\
$9^{\text {th }}$ decile & 29.5 & 21.5 & 22.0 & 15.8 & 48.6 & 62.6
\end{tabular}


\begin{tabular}{lllllll}
$10^{\text {th }}$ decile & 19.7 & 12.7 & 20.2 & 12.7 & 60.0 & 74.6 \\
\hline
\end{tabular}

Source: WBO 1998 and WBO 2002, own calculations (weighted)

Tables 5 and 6 focus on the role of ethnicity/foreign origin in tenure segmentation. In general, the percentage of ethnic households in social rented housing is higher than for the indigenous Dutch, with the exception of the Indonesian community. Even more interesting is that these changes are less pronounced than changes with respect to income. This is especially true in the four largest cities. Furthermore, the share of Turks and Moroccans in owner-occupation has increased; some members of these groups have apparently become homeowners. This gradual shift, which has also been noted in other research papers, suggests that ethnic households with middle and higher incomes are also leaving the social rented sector.

Table 5: $\quad$ Ethnicity/foreign origin and tenure in the Netherlands, 1998 and 2002 (percentages per population category)

\begin{tabular}{lllllll}
\hline & \multicolumn{2}{l}{ Social rent } & \multicolumn{2}{l}{ Private rent } & \multicolumn{2}{c}{ Owner-occupation } \\
\cline { 2 - 7 } & 1998 & 2002 & 1998 & 2002 & 1998 & 2002 \\
\hline Total & 36.7 & 35.0 & 12.4 & 10.8 & 50.8 & 54.2 \\
& & & & & & \\
Dutch & 34.7 & 33.0 & 12.2 & 9.6 & 53.2 & 57.4 \\
Sur/Ant/Ar & 63.3 & 63.4 & 11.6 & 11.2 & 25.1 & 25.4 \\
Indonesian & 36.6 & 39.6 & 16.4 & 11.9 & 47.0 & 48.5 \\
Turks/Moroccans & 80.1 & 77.4 & 11.1 & 8.0 & 8.8 & 14.6 \\
\hline
\end{tabular}

Source: WBO 1998 and WBO 2002, own calculations (weighted)

Table 6: $\quad$ Ethnicity/foreign origin and tenure in the four largest cities of the Netherlands, 1998 and 2002 (percentages per population category)

\begin{tabular}{lllllll}
\hline & \multicolumn{2}{l}{ Social rent } & \multicolumn{3}{c}{ Private rent } & \multicolumn{2}{c}{ Owner-occupation } \\
\cline { 2 - 7 } & 1998 & 2002 & 1998 & 2002 & 1998 & 2002 \\
\hline Total & 51.5 & 49.6 & 23.2 & 20.9 & 25.3 & 29.5 \\
& & & & & & \\
Dutch & 46.3 & 45.4 & 27.1 & 21.3 & 26.6 & 33.3 \\
Sur/Ant/Ar & 68.3 & 68.5 & 15.2 & 14.2 & 16.5 & 17.2 \\
Indonesian & 38.9 & 39.2 & 29.3 & 23.9 & 31.8 & 36.9 \\
Turks/Moroccans & 75.5 & 75.4 & 18.1 & 12.7 & 6.4 & 11.9 \\
\hline
\end{tabular}

Source: WBO 1998 and WBO 2002, own calculations (weighted)

Because the above results may reflect changes in household composition, we also tested our hypotheses using multivariate models. Table 7 shows three logistic regression models of the probability to live in an owner-occupied or a social rented dwelling. The reference category is owner-occupation, and persons in private rent were excluded from the analyses. Model 1 includes income, household composition, age, ethnicity/foreign origin, location and year of interview. The results are as expected: the probability that a household will be living in social rented housing increases with decreasing income. People in the lowest income quartiles have the highest likelihood of living in social rented units. Compared to family households, all other household categories have a higher probability to live in a social rented dwelling. The likelihood is greatest among singles and single-parent households. With increasing age, the probability that a person will live in the social rented sector decreases. The effect of age is not linear, though; over age 65, the probability of living in a social rented dwelling increases slightly. Compared to the indigenous Dutch, ethnic households are more likely to be in social rented housing; Turks and 
Moroccans have the highest probability. Households living in one of the four largest cities in the Netherlands have a higher probability to live in social rented housing than households in the rest of the Netherlands.

All of the above results are as expected. The social rented sector is home to those with a low income, to singles and single parents, to young people, to people with an ethnic background or of foreign origin, and to city dwellers. The fact that those in the four largest cities more often live in social rented housing reflects the housing stock in these cities. To test whether the effect of income on the probability of living in social rented housing changed between 1998 and 2002, we also included interaction terms between income quartiles and year of interview in Model 2. Expanding the model to include these interaction terms hardly changed the parameters of the other variables in the model, except for the effect of year of interview. Adding up the main effects of income, year, and the interaction effects reveals that those in the highest income quartile had a much lower probability to live in a social rented dwelling compared to 1998. Also those in the second and third income quartile had a somewhat lower probability to live in the social rented sector in 2002; those in the lowest income quartile had a somewhat higher probability. This outcome shows that the decrease in the supply of social rented housing between 1998 and 2002 - from almost 37 to 35 percent of the stock - has marginalized the social rented sector somewhat; higher-income households have moved to the owner-occupied sector (or bought their home from the housing associations).

In Model 3 we tested whether the effect of ethnicity/foreign origin on the probability of living in social rented housing changed between 1998 and 2002. For this purpose we included interaction terms between ethnic group and year of interview. It was expected that the social rented sector increasingly became home to ethnic-minority/foreign-origin groups in the Netherlands. Interestingly, adding up the main effects of ethnicity/foreign origin, year and the interaction effects reveals that all groups had a lower probability to live in the social rented sector in 2002. This indicates that marginalization of the social sector is only in terms of income, not in terms of ethnicity/foreign origin.

Table 7 Logistic regression model of the probability to live in an owneroccupied home (0) or a social rented home (1), 1998 and 2002

\begin{tabular}{|c|c|c|c|c|c|c|c|c|c|c|c|c|}
\hline \multirow{3}{*}{$\begin{array}{l}\text { Income segment of the hh } \\
\text { highest } 25 \%\end{array}$} & \multicolumn{4}{|c|}{ Model 1} & \multicolumn{4}{|c|}{ Model 2} & \multicolumn{4}{|c|}{ Model 3} \\
\hline & B & S.E. & & $\operatorname{Exp}(B)$ & B & S.E. & & $\operatorname{Exp}(B)$ & B & S.E. & & $\operatorname{Exp}(B)$ \\
\hline & 0.000 & & & & 0.000 & & & & 0.000 & & & \\
\hline 3rd $25 \%$ & 0.976 & 0.020 & $* * *$ & 2.653 & 0.913 & 0.025 & $* * *$ & 2.493 & 0.913 & 0.025 & $* * *$ & 2.491 \\
\hline 2nd $25 \%$ & 1.764 & 0.021 & $* * *$ & 5.835 & 1.692 & 0.025 & $* * *$ & 5.431 & 1.691 & 0.025 & $* * *$ & 5.427 \\
\hline lowest $25 \%$ & 2.151 & 0.023 & $* * *$ & 8.596 & 1.980 & 0.027 & $* * *$ & 7.244 & 1.981 & 0.027 & $* * *$ & 7.250 \\
\hline $\begin{array}{l}\text { Household composition } \\
\text { family household }\end{array}$ & 0.000 & & & & 0.000 & & & & 0.000 & & & \\
\hline Single & 1.014 & 0.019 & $* * *$ & 2.756 & 1.011 & 0.019 & $* * *$ & 2.748 & 1.011 & 0.019 & $* * *$ & 2.747 \\
\hline two-person household & 0.544 & 0.018 & $* * *$ & 1.722 & 0.540 & 0.018 & $* * *$ & 1.717 & 0.541 & 0.018 & $* * *$ & 1.717 \\
\hline one-parent household & 1.321 & 0.031 & $* * *$ & 3.748 & 1.319 & 0.031 & $* * *$ & 3.740 & 1.319 & 0.031 & $* * *$ & 3.740 \\
\hline $\begin{array}{l}\text { Age head of the hh } \\
\text { under } 25\end{array}$ & 0.000 & & & & 0.000 & & & & 0.000 & & & \\
\hline $25-44$ & -0.956 & 0.044 & $* * *$ & 0.384 & -0.951 & 0.044 & $* * *$ & 0.386 & -0.951 & 0.044 & $* * *$ & 0.386 \\
\hline $45-54$ & -1.086 & 0.045 & $* * *$ & 0.337 & -1.080 & 0.045 & $* * *$ & 0.340 & -1.080 & 0.045 & $* * *$ & 0.340 \\
\hline $55-64$ & -1.140 & 0.045 & $* * *$ & 0.320 & -1.132 & 0.045 & $* * *$ & 0.322 & -1.132 & 0.045 & $* * *$ & 0.322 \\
\hline $65-74$ & -0.839 & 0.045 & $* * *$ & 0.432 & -0.828 & 0.045 & $* * *$ & 0.437 & -0.828 & 0.045 & $* * *$ & 0.437 \\
\hline over 75 & -0.613 & 0.047 & $* * *$ & 0.542 & -0.603 & 0.047 & $* * *$ & 0.547 & -0.603 & 0.047 & $* * *$ & 0.547 \\
\hline Ethnicity of head of hh & 0000 & & & & 0000 & & & & 0000 & & & \\
\hline
\end{tabular}




\begin{tabular}{|c|c|c|c|c|c|c|c|c|c|c|c|c|}
\hline Sur/Ant/Ar & 1.071 & 0.045 & $* * *$ & 2.920 & 1.067 & 0.045 & $* * *$ & 2.907 & 1.091 & 0.057 & $* * *$ & 2.979 \\
\hline Indonesian & 0.368 & 0.036 & $* * *$ & 1.445 & 0.369 & 0.036 & $* * *$ & 1.446 & 0.291 & 0.045 & $* * *$ & 1.337 \\
\hline Turks/Moroccans & 2.528 & 0.054 & $* * *$ & 12.530 & 2.531 & 0.054 & $* * *$ & 12.570 & 2.753 & 0.077 & $* * *$ & 15.691 \\
\hline \multicolumn{13}{|l|}{ Location of residence } \\
\hline Rest of Netherlands & 0.000 & & & & 0.000 & & & & 0.000 & & & \\
\hline 4 largest cities & 0.817 & 0.020 & $* * *$ & 2.264 & 0.819 & 0.021 & $* * *$ & 2.269 & 0.820 & 0.021 & $* * *$ & 2.270 \\
\hline \multicolumn{13}{|l|}{ Year } \\
\hline 1998 & 0.000 & & & & 0.000 & & & & 0.000 & & & \\
\hline 2002 & -0.176 & 0.013 & $* * *$ & 0.839 & $-0,425$ & 0,035 & $* *$ & 1.060 & -0.426 & 0.035 & $* * *$ & 0.653 \\
\hline \multicolumn{13}{|l|}{ Interaction income*2002 } \\
\hline 3rd 25\% * 2002 & & & & & 0.193 & 0.043 & $* * *$ & 1.212 & 0.196 & 0.043 & $* * *$ & 1.217 \\
\hline 2nd $25 \% * 2002$ & & & & & 0.220 & 0.042 & $* * *$ & 1.246 & 0.224 & 0.042 & $* * *$ & 1.251 \\
\hline lowest $25 \% * 2002$ & & & & & 0.483 & 0.043 & $* * *$ & 1.622 & 0.484 & 0.043 & $* * *$ & 1.622 \\
\hline \multicolumn{13}{|l|}{ Interaction ethnicity $* 2002$} \\
\hline Dutch $* 2002$ & & & & & & & & & 0.000 & & & \\
\hline Sur/Ant/Ar * 2002 & & & & & & & & & -0.065 & 0.091 & & 0.938 \\
\hline Indonesian * 2002 & & & & & & & & & 0.215 & 0.074 & $* * *$ & 1.240 \\
\hline Turks/Moroccans $* 2002$ & & & & & & & & & -0.477 & 0.108 & $* * *$ & 0.620 \\
\hline Constant & -1.418 & 0.048 & $* * *$ & 0.242 & -1.340 & 0.049 & $* * *$ & 0.262 & -1.341 & 0.049 & $* * *$ & 0.262 \\
\hline Initial -2 LLikelihood & 191.846 & & & & 191.846 & & & & 191.84 & & & \\
\hline Model -2 LLikelihood & 148.674 & & & & 148.532 & & & & 148.50 & & & \\
\hline Improvement & 43.171. d & $f=16 . p$ & $=0.00$ & & 43.314. & $=19 . p=$ & & & 43.343. & $\mathrm{df}=22 \cdot \mathrm{p}$ & 0.00 & \\
\hline
\end{tabular}

Source: WBO 1998 and WBO 2002, own calculations

\section{Conclusions}

A review of the published writings of Frans Dieleman shows that the Dutch social rented sector consistently held his interest. Much of this work was what he called 'curiosity-driven': he simply wanted to understand how the housing market worked and sought empirical evidence to test his hypotheses, mainly using large datasets and quantitative methods. He usually combined his urge to understand how the housing market worked with commentary - aimed at policy-makers - on the social outcomes of the housing market.

One of the main characteristics of the Dutch housing market is the presence of a large stock of social rented housing. Strong support by the public sector established and maintained this large and predominantly good-quality stock, grounded in a broad coalition of political parties. Dieleman's knowledge of the housing system in the United States had made him aware of the social benefits offered by the Dutch housing system, with its abundance of affordable social rented units. But at the same time, he was also aware of the possibly unsustainable (financial) burden the social rented sector might put on the public sector in the future.

Indeed, since the end of the 1980s, Dutch housing-policy memorandums stated repeatedly that it was unwise to continue building inexpensive social rented dwellings in massive numbers. Because of the rising building costs and the related rise in (supply- and demand-side) subsidies, and because many social rented dwellings were inhabited by households that did not have low incomes, it was advocated that the owner-occupied sector should be expanded. While the owner-occupied sector was deemed to play a more prominent role on the Dutch housing market, at the same time state subsidies for social rented housing were supposed to be diminished. The direct effect was a growing stock of owner-occupied dwellings. A subsequent effect was the increasing concentration of low-income households in the social rented sector, 
especially because higher-income households could find a home in the newly built owner-occupied dwellings.

Frans Dieleman and his co-authors have always stressed the importance of income in explaining the housing situations of households. They devoted considerably less attention to the ethnic variable. Also in the analysis in the present article, household income turns out to be an important predictor of the housing situation. It is clear that in the most recent period for which we could get data (1998-2002) the households belonging to the lowest income deciles are increasingly concentrated in the social rented sector. On the one hand this can be seen as a desirable option: social rented dwellings were in fact built for those who could not afford to live in the owneroccupied sector. The out-migration of higher-income people leads to vacancies in the social rented stock, thereby opening up opportunities for those with lower incomes. However, this increasing concentration of low-income households may be accompanied by a process of residualization, whereby an increasing number of lowincome households would be living in the worst parts of the housing stock. Clearly, such a situation is much less desirable. Although the analysis shows that ethnic minorities are overrepresented in social housing, the results also indicate that there is no marginalization of the social sector in terms of ethnic background. Compared to 1998, all groups had a lower probability to live in the social rented sector in 2002 . The fact that marginalization of the social sector is only occurring in terms of income might mean that ethnic minorities are faced with fewer barriers to homeownership.

Frans Dieleman understood why the more affluent households would leave the social rented sector: they sought the greater freedom afforded by homeownership and the promise of capital gains. From his writings, we sense that he believed people should try to rely on their own resources, rather than depend on the state. But his writings also suggest that people who cannot obtain decent housing on their own accord ought to have access to a decent rented dwelling at a price they could afford. In that regard, he saw social rented housing as a highly valuable asset, even though he had to conclude that it put an unsustainable burden on the state.

\section{References}

Aalbers, M. (2003), Redlining in Nederland. Oorzaken en gevolgen van uitsluiting op de hypotheekmarkt. Amsterdam: Aksant.

Boelhouwer, P. \& H. Priemus (1990), Dutch housing policy realigned. In: Netherlands Journal of Housing and Environmental Research, 5, pp. 105-119.

CBS (2005), Statistisch Jaarboek. Statistics Netherlands. Heerlen/Voorburg.

CBS Statline (2005), Statline (www.statline.nl). Statistics Netherlands. Heerlen/Voorburg.

Clark, W.A.V., M.C. Deurloo \& F.M. Dieleman (1984), Residential mobility and housing adjustment. In: Annals of the Association of American Geographers, pp. 29-43.

Clark, W.A.V., M.C. Deurloo \& F.M. Dieleman (1986), Residential mobility in Dutch housing markets. In: Environment and Planning A, 18, pp. 763-788.

Clark, W.A.V., M.C. Deurloo \& F.M. Dieleman (1988), Modeling strategies for categorical data: Examples from housing and tenure choice. In: Geographical Analysis, 20, pp. 196-219.

Clark, W.A.V. \& F.M. Dieleman (1996), Households and Housing: Choice and Outcomes in the Housing Market. New Jersey: Center for Urban Policy Research. 
Deurloo, M.C., F.M. Dieleman \& W.A.V. Clark (1987), Tenure choice in the Dutch housing market. In: Environment and Planning A, 19, pp. 763-781.

Dieleman, F.M. (1971a), De centrale plaatsen theorie van Christaller. In: Geografisch Tijdschrift, 80, pp. 453-563.

Dieleman, F.M. (1971b), Factoranalyse en multidimensionale groepering. In: Tijdschrift voor Economische en Sociale Geografie, pp. 217-225.

Dieleman, F.M. (1986), The future of Dutch housing: A review and interpretation of the recent literature. In: Tijdschrift voor Economische en Sociale Geografie, 77 (5), pp. 336-344.

Dieleman, F.M. (1994). Social rented housing: Valuable asset or unsustainable burden? In: Urban Studies, 31, pp. 447-463.

Dieleman, F.M. \& R. Jobse (1974), An economic spatial structure of Amsterdam. In: Tijdschrift voor Economische en Sociale Geografie, 65 (5), pp. 351-367.

Dieleman, F.M. \& J. van Weesep (1986), Housing under fire: budget cuts, policy adjustments and market changes. In: Tijdschrift voor Economische en Sociale Geografie, 77, pp. 310-315.

Dieleman, F.M. \& H. Priemus (eds.) (1988), Beyond social housing. In: Built Environment, 14, pp. 139-219 (special issue).

Heida, H.R. \& H.E. Gordijn (1985), Het PRIMOS-huishoudensmodel. Delft: Planologisch Studiecentrum/TNO.

Meusen, H. \& R. van Kempen (1994), Dutch Social Rented Housing: A British Experience? Bristol: School for Advanced Urban Studies, University of Bristol.

Meusen, H. \& R. van Kempen (1995), Towards residual housing? A comparison of Britain and the Netherlands. In: Netherlands Journal of Housing and the Built Environment, 10, pp. 239-258.

Ministerie VROM (1989), Nota Volkshuisvesting in de jaren negentig. Den Haag: Sdu Uitgevers.

Ministerie VROM (1997), Nota stedelijke Vernieuwing. Den Haag: Ministerie van VROM.

Ministerie VROM (2000), Cijfers over wonen 2000/2001: Feiten over mensen, wensen, wonen. Ministerie van Volkshuisvesting. Ruimtelijke Ordening en Milieubeheer. Den Haag.

Ministerie VROM (2004), Cijfers over wonen 2004: Feiten over mensen, wensen, wonen. Ministerie van Volkshuisvesting. Ruimtelijke Ordening en Milieubeheer. Den Haag.

Murie, A. \& H. Priemus (1994), Social rented housing in Britain and the Netherlands: Trends, trajectories and divergence. In: Netherlands Journal of Housing and the Built Environment, 9, pp. 107-126.

Musterd, S. \& F.M. Dieleman (1981), Scaling methods: measurement of the service level of centers in Noord-Brabant (The Netherlands). In: Tijdschrift voor Economische en Sociale Geografie, 72, pp. 310-315.

Priemus, H. (1995), How to abolish social housing? The Dutch case. In: International Journal of Urban and Regional Research, 19, pp. 145-155.

Priemus, H. \& F.M. Dieleman (2002), Social housing policy in the European Union. In: Urban Studies, 39 (2), pp. 191-200.

Schutjens, V.A.J.M., R. van Kempen \& J. van Weesep (2002), The changing tenant profile of Dutch social rented housing. In: Urban Studies, 39 (4), pp. 643-664.

Van Kempen, R. \& H. Priemus (2002), Revolution in social housing in the Netherlands: possible effects of new housing policies. In: Urban Studies, 39 (2), pp. 237-253. 
Van Kempen, R., V.A.J.M. Schutjens \& J. van Weesep (2000), Housing and social fragmentation in the Netherlands. In: Housing Studies, 15 (4), pp. 505-531.

Van Kersbergen, K. \& U. Becker (1988), The Netherlands: a passive social democratic welfare state in a Christian Democratic ruled society. In: Journal of Social Policy, 17, pp. 477-499. 